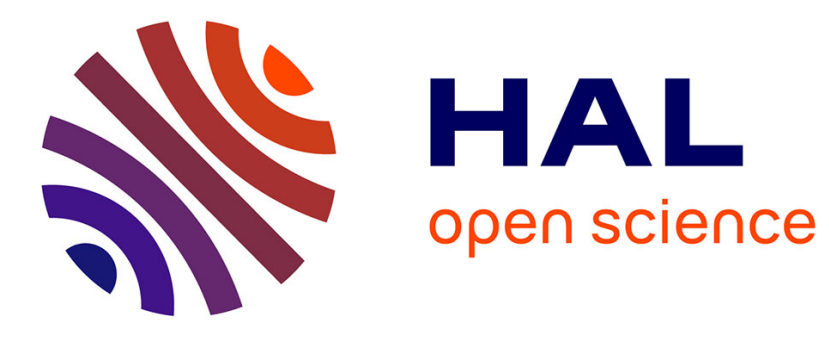

\title{
Spirokermeline: A Macrocyclic Spirolactone from Kermadecia elliptica Brongn. \& Gris
}

Mays Khazem, Claire Jolly, Thomas Gaslonde, Stéphane Massip, Philippe

Négrier, Philippe Espeau, Sylvie Michel, Marc Litaudon

\section{To cite this version:}

Mays Khazem, Claire Jolly, Thomas Gaslonde, Stéphane Massip, Philippe Négrier, et al.. Spirokermeline: A Macrocyclic Spirolactone from Kermadecia elliptica Brongn. \& Gris. European Journal of Organic Chemistry, 2018, 2018 (42), pp.5819-5822. 10.1002/ejoc.201800259 . hal-01953282

\section{HAL Id: hal-01953282 \\ https://hal.science/hal-01953282}

Submitted on 12 Dec 2018

HAL is a multi-disciplinary open access archive for the deposit and dissemination of scientific research documents, whether they are published or not. The documents may come from teaching and research institutions in France or abroad, or from public or private research centers.
L'archive ouverte pluridisciplinaire HAL, est destinée au dépôt et à la diffusion de documents scientifiques de niveau recherche, publiés ou non, émanant des établissements d'enseignement et de recherche français ou étrangers, des laboratoires publics ou privés.

\section{(1)(1) $\$(0)$}

Distributed under a Creative Commons Attribution - NonCommercial - ShareAlikel 4.0 


\title{
Spirokermeline: A Macrocyclic Spirolactone from Kermadecia elliptica Brongn. \& Gris
}

\author{
Mays Khazem, ${ }^{[a]}$ Claire Jolly, ${ }^{[e]}$ Thomas Gaslonde, ${ }^{*[a]}$ Stéphane Massip, ${ }^{[b]}$ Philippe Negrier, ${ }^{[c]}$ \\ Philippe Espeau, ${ }^{[\mathrm{d}]}$ Sylvie Michel, ${ }^{[\mathrm{a}]}$ and Marc Litaudon*[e]
}

\begin{abstract}
Spirokermeline, a new macrocyclic compound derived from resorcinol, was isolated from Kermadecia elliptica, an endemic species of New Caledonia. The structure of spirokermeline was elucidated on the basis of spectroscopic analysis and X-ray single-crystal diffraction analysis. This is the first time
\end{abstract}

\section{Introduction}

The genus Kermadecia (Proteaceae) is well represented in New Caledonia with four endemic species. From the bark of $K$. elliptica and $K$. rotundifolia, Litaudon and colleagues reported the isolation of twelve derivatives with a (14- $p, 0-o)$ cyclophane skeleton, which were given the trivial name "kermadecin". ${ }^{[1,2]}$ Kermadecins resulted from the cyclization of bisresorcinol derivatives in cyclophane, leading to turriane-type kermadecin ${ }^{[3]}$ (1) exemplified by kermadecin A (3), and robustol-type kermadecin (2) exemplified by kermadecin D (4), Figure 1. ${ }^{[4]}$ Kermadecins A and $B$ showed significant cytotoxic activities against $K B$ and L1210 cancer cell lines, whereas kermadecins D and J and isokermadecin $D$ exhibited a good inhibitory effect on acetylcholinesterase. ${ }^{[1,2]}$ Recently, a series of derivatives of kermadecin A has been synthesized from the natural product to conduct structure-activity relationship studies. ${ }^{[5]}$ These studies required the extraction of $16 \mathrm{~kg}$ of barks of $K$. elliptica leading to the isolation of $450 \mathrm{mg}$ of kermadecin A after several purification

[a] Laboratoire de Pharmacognosie, UMR/CNRS 8638, Université Paris Descartes, Sorbonne Paris Cité, Faculté de Pharmacie de Paris, 4 avenue de l'Observatoire, 75006 Paris, France E-mail: thomas.gaslonde@parisdescartes.fr

[b] Université Bordeaux, Institut Européen de Chimie et de Biologie (CNRS UMS 3033/ INSERM US001),

2 rue Escarpit, 33600 Pessac, France

[c] Laboratoire Ondes et Matière D'Aquitaine UMR 5798 au CNRS, Université Bordeaux,

351 cours de la Libération, 33405 Talence Cedex, France

[d] Unité de Technologies Chimiques et Biologiques pour la Santé (UTCBS) CNRS UMR 8258, INSERM UMR-S 1022, Faculté de Pharmacie de Paris, Université Paris-Descartes,

4 avenue de l'Observatoire, 75006 Paris, France

[e] Institut de Chimie des Substances Naturelles, CNRS-ICSN UPR2301, Université Paris-Saclay,

Avenue de la Terrasse, 91198 Gif-sur-Yvette Cedex, France marc.litaudon@cnrs.fr www.icsn.cnrs-gif.fr that a $3 H, 3^{\prime} H$-spiro[benzofuran-2, $1^{\prime}$-isobenzofuran]-3,3'-dione was isolated from higher plants and only the second time that this scaffold was found in nature. A possible biosynthetic pathway is proposed.

steps. The investigation of one of the apolar chromatographic fractions has led to the isolation of a minor metabolite of this plant possessing a 2,9-dioxo-1,6-dioxaspiro[4,4]nona-3,7-dien moiety described for the second time in nature. To the best of our knowledge, nidulal, an inducer of differentiation of human HL-60 promyeocytic leukemia cells isolated from the basidiomycete Nidula candida was the only natural product possessing such a spirobicyclic moiety. ${ }^{[6]}$ However, the first synthesis of a compound possessing such a spiro substructure took place more than 35 years ago. ${ }^{[7]}$ This subunit can be found in the structure of fluorescamine, a reagent that reacts with primary amines to yield intensely fluorescent substances. ${ }^{[8]}$ Also, this subunit is present in various spiro lactones, ${ }^{[9]}$ some of which have shown interesting antiviral properties against influenza viruses.<smiles>Clc1ccccc1-c1ccccc1</smiles>

1

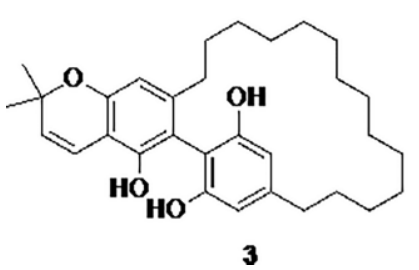

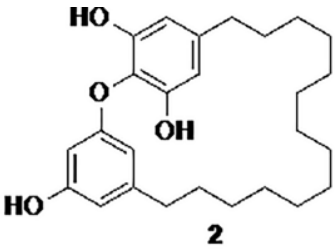

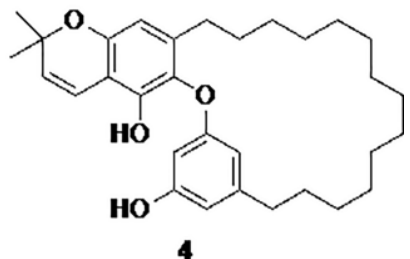

Figure 1. Turriane ring system (1), robustol (2), kermadecin A (3), and kermadecin $D(\mathbf{4})$.

\section{Results and Discussion}

The bark (16 kg) of Kermadecia elliptica Brongn. \& Gris was collected in 2008 in New Caledonia at "Forêt plate" (UTM 0511686/ 7663347, elevation $328 \mathrm{~m}$ ), and was extracted with ethyl acet- 
ate at $40{ }^{\circ} \mathrm{C}$ under a pressure of 100 bars. The corresponding voucher specimen POU-0289 is kept at the Herbarium of the IRD Center, Nouméa, New Caledonia. The chemical investigation of this extract led to the isolation of a new macrocyclic compound, named spirokermeline (5), together with 13 known compounds, $\beta$-sitosterol and $\beta$-sitostenone, trans-docosanyl and trans-cosanyl ferulate, ${ }^{[10]}$ vanillin, lignoceric acid, kermadecins $A-F$, and isokermadecin $D .^{[1,2]}$ The structures of the known compounds were unambiguously determined by ${ }^{1} \mathrm{H}$ and ${ }^{13} \mathrm{C}$ NMR analysis, and through comparison with spectroscopic data reported in the literature.

Compound 5, obtained as a white solid (9 mg), showed a protonated molecule ion at $\mathrm{m} / \mathrm{z} 479.279259$ (calcd. 479.279201) in $\mathrm{HRESI}(+) \mathrm{MS}$, corresponding to the molecular formula, $\mathrm{C}_{30} \mathrm{H}_{38} \mathrm{O}_{5}$. When compared with the formula of almost all kermadecins, we noticed that compound $\mathbf{5}$ had one less carbon atom. The IR spectrum of $\mathbf{5}$ showed absorption bands at 1610, 1721 , and $1789 \mathrm{~cm}^{-1}$ for $\alpha, \beta$-unsaturated ketone and $\alpha, \beta$-unsaturated $\gamma$-lactone functions. The ${ }^{1} \mathrm{H}$ NMR and ${ }^{13} \mathrm{C}$ NMR spectroscopic data (Table 1 ) revealed the presence of a penta-substituted aromatic ring (ring A), a long carbon chain, and signals assignable to a 2,2-dimethylpyran ring (ring B). In the $\mathrm{HMBC}$ spectrum, correlations observed from the vinylic proton $\mathrm{H}-26$ at $\delta_{\mathrm{H}}=6.46 \mathrm{ppm}(\mathrm{d}, J=10.6 \mathrm{~Hz})$ to carbon atoms C-21 $\left(\delta_{\mathrm{C}}=\right.$ $167.6 \mathrm{ppm}), \mathrm{C}-22\left(\delta_{\mathrm{C}}=104.5 \mathrm{ppm}\right), \mathrm{C}-23\left(\delta_{\mathrm{C}}=162.4 \mathrm{ppm}\right)$, and $\mathrm{C}-28\left(\delta_{\mathrm{C}}=79.1 \mathrm{ppm}\right)$, and from $\mathrm{H}-26$ and $\mathrm{H}-27$ to $\mathrm{C}-28$, which bears two equivalent methyl groups at $\delta_{\mathrm{C}}=29.0 \mathrm{ppm}$, suggested that the dimethylpyran ring system is fused to the aromatic ring $A$ as depicted in Figure 2.

Table 1. ${ }^{1} \mathrm{H}(300 \mathrm{MHz})$ and ${ }^{13} \mathrm{C}(75 \mathrm{MHz})$ data of spirokermeline (5) in $\mathrm{CDCl}_{3}$.

\begin{tabular}{lll}
\hline Position & $\delta_{\mathrm{H}}$ [ppm], mult. $(\mathrm{J}$ in Hz) & $\delta_{\mathrm{C}}[\mathrm{ppm}]$ \\
\hline $1 \mathrm{a}$ & $2.57, \mathrm{~m}$ & 31.9 \\
$1 \mathrm{~b}$ & $3.07, \mathrm{~m}$ & \\
2 & $1.55, \mathrm{~m}$ & 30.1 \\
3 to 12 & $1.24-1.36, \mathrm{~m}$ & $27.2-30.0$ \\
13 & $1.70, \mathrm{~m}$ & 30.6 \\
$14 \mathrm{a}$ & $2.35, \mathrm{~m}$ & 25.2 \\
$14 \mathrm{~b}$ & $2.55, \mathrm{~m}$ & \\
15 & - & 140.4 \\
16 & $6.69, \mathrm{~s}$ & 140.3 \\
17 & - & 105.9 \\
18 & - & 170.5 \\
19 & - & 188.7 \\
20 & - & 110.1 \\
21 & - & 167.6 \\
22 & - & 104.5 \\
23 & - & 162.4 \\
24 & $6.36, \mathrm{~s}$ & 113.5 \\
25 & - & 148.0 \\
26 & $6.46, \mathrm{~d}(10.6)$ & 114.4 \\
27 & $5.61, \mathrm{~d}(10.6)$ & 129.2 \\
28 & - & 79.1 \\
29 & $1.47, \mathrm{~s}$ & 29.0 \\
30 & $1.48, \mathrm{~s}$ & 29.0 \\
\hline
\end{tabular}

Long-range correlations from $\mathrm{H}-24$ to $\mathrm{C}-1, \mathrm{C}-19, \mathrm{C}-20, \mathrm{C}-22$, and $\mathrm{C}-23$ in the $\mathrm{HMBC}$ spectrum, confirmed the location of a ketone function $\left(\delta_{\mathrm{C}}=188.7 \mathrm{ppm}, \mathrm{C}-19\right)$ at $\mathrm{C}-19$, and an aliphatic chain to C-25. The presence of a 2,9-dioxo-1,6-dioxaspiro[4,4]-

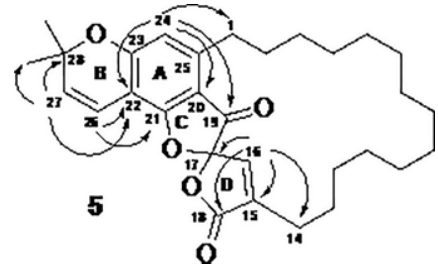

Figure 2. Key HMBC correlations for spirokermeline (5).

nona-3,7-dien moiety can be deduced from long-range correlations between the vinylic proton at $\delta_{\mathrm{H}}=6.69 \mathrm{ppm}(\mathrm{H}-16)$ with $\mathrm{C}-14, \mathrm{C}-15, \mathrm{C}-17$, and $\mathrm{C}-18$, and from the chemical shift of $\mathrm{C}-17$ at $\delta_{\mathrm{C}}=105.9 \mathrm{ppm}$, typical of a hemiketal carbon. From these data, it can be proposed that the furanone ring $C$ is fused to the benzopyran unit through $\mathrm{C}-20$ and $\mathrm{C}-21$, and that a 14carbon aliphatic chain is attached to ring $\mathrm{A}$ at $\mathrm{C}-25$. However, the substitution of the lactone ring $D$ at the alpha or beta position with the long aliphatic chain still needs to be established.

The structure of compound $\mathbf{5}$ was finally confirmed by single-crystal X-ray diffraction (deposition number: CCDC 1822347). The asymmetric unit obtained from X-ray analysis is presented in Figure 3. This study permitted us to confirm that the 14-carbon aliphatic chain was attached to $\mathrm{C}-15$, in the alpha position of the carbonyl group. In addition, asymmetric carbon atom 17 found in the structure solved in the $P 2_{1} / C$ centrosymmetric space group indicates that $R$ and $S$ enantiomers are present in the unit cell. Consequently, the natural spirokermeline occurs as a racemic mixture, as confirmed by the specific rotation value of $5[\alpha]_{D}^{22}=0\left(c=0.65, \mathrm{CHCl}_{3}\right)$. The details of this study are presented in the Supporting Information, including the crystal data and the structure refinement of the racemic compound.

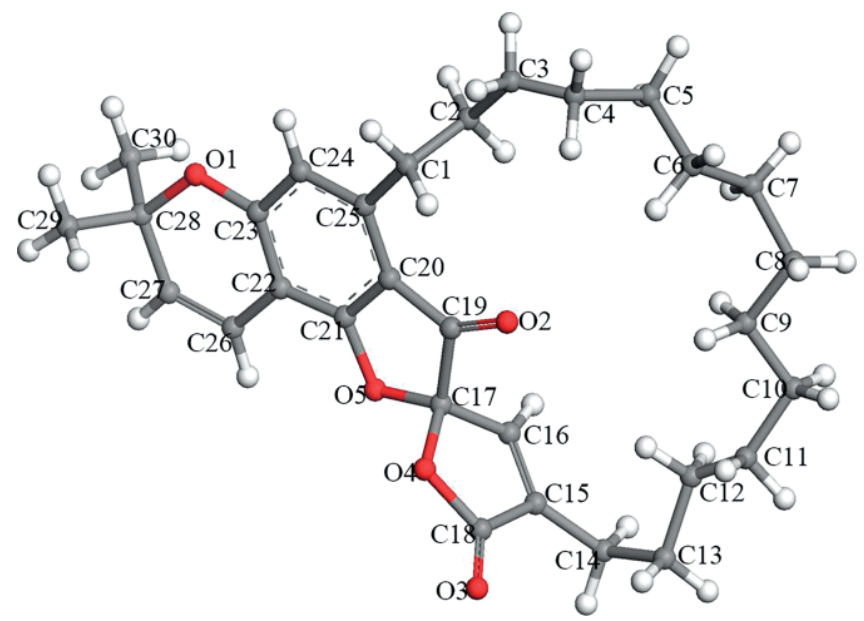

Figure 3. Asymmetric unit of of spirokermeline (5) with atom numbering obtained from X-ray diffraction.

A plausible biosynthetic pathway for spirokermeline was postulated (Scheme 1). Isokermadecin $F(6)$, which results from a first oxidation of kermadecin $A$ to quinone, could give a 1,2-dioxetane intermediate in the presence of singlet oxygen. A spontaneous rearrangement of the dioxetane ring leads to a pyruvic acid derivative easily decarboxylated and oxidized under oxidiz- 
ing (or enzymatic) conditions into the corresponding carboxylic acid derivative $\mathbf{7}$ as depicted in Scheme 1. The mechanism of decarboxylation of pyruvic acid into carboxylic acid in the presence of $\mathrm{H}_{2} \mathrm{O}_{2}$ has been studied by Lopalco and co-workers. ${ }^{[1]}$ Afterwards, attack of the phenol group onto the ketone carbonyl group would form ring $C$ and then the butyrolactone $D$ as indicated previously by Letcher and co-workers. ${ }^{[12]}$

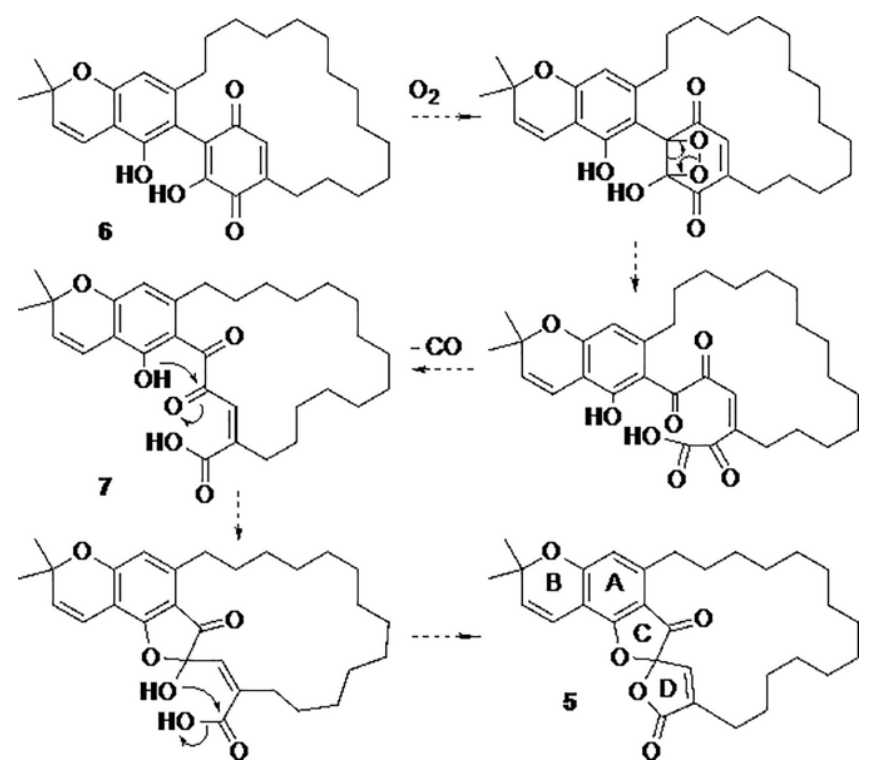

Scheme 1. Plausible biosynthesis of spirokermeline (5) from isokermadecin F (6).

Some spiro lactones were shown to exhibit potent antiviral activities against influenza B virus, ${ }^{[9]}$ therefore, spirokermeline $\mathbf{5}$ was evaluated for its antiviral activity against influenza $A / H 1 N 1$, influenza A/H3N2, influenza B, HIV-I (IIIB strain), and HIV-2 (ROD strain) viruses, but was found inactive at a concentration up to $100 \mu \mathrm{M}$ on all viruses tested (see the Supporting Information). In addition, spirokermeline was subjected to cytotoxic assays against HCT116 colon, K562 leukemia, and U87 glioblastoma human cancer cell lines, and to an antibacterial assay against a panel of 52 Gram-positive and Gram-negative strains (see the Supporting Information). Spirokermeline did not show any cytotoxic or antibacterial activities at a concentration up to $10 \mu \mathrm{M}$ and $50 \mathrm{mg} / \mathrm{L}$, respectively.

\section{Conclusions}

Spirokermeline (5), a new rearranged macrocyclic cyclophane was isolated from the bark of Kermadecia elliptica. This compound is the second example of a naturally occurring $3 \mathrm{H}, 3^{\prime} \mathrm{H}$ spiro[benzofuran-2, ' $^{\prime}$-isobenzofuran]-3,3'-dione derivative, and the first example from higher plants. Although we cannot rule out an artifactual origin, it is likely that spirokermelin is a genuine natural product. Indeed, two different chemical investigations were conducted in 2008 and 2016 from 3 and $16 \mathrm{~kg}$ of barks, ${ }^{[1,5]}$ respectively, leading to the isolation of spirokermelin in comparable yields $(\approx 0.000033 \%$ and $0.000056 \%$, respectively).

\section{Experimental Section}

Plant Material: The bark of Kermadecia elliptica was collected in 2008 at "Forêt plate" (New Caledonia). The corresponding voucher specimen POU-0289 has been deposited at the Herbier IRD de Nouméa (NOU), New Caledonia.

Extraction and Isolation: Air-dried material (16 kg) was extracted with EtOAc $(2 \times 4.5 \mathrm{~L}, 1 \mathrm{~h}$ each $)$ at $40^{\circ} \mathrm{C}$ under 100 bars and concentrated under vacuum at $40{ }^{\circ} \mathrm{C}$. The EtOAc extract $(70 \mathrm{~g}$ ) was subjected to a silica gel column chromatography using a gradient of cyclohexane $/ \mathrm{CH}_{2} \mathrm{Cl}_{2}$ (100:0 to $\left.0: 100\right)$ and $\mathrm{CH}_{2} \mathrm{Cl}_{2} / \mathrm{MeOH}$ (100:0 to $80: 20$ ) to give 26 fractions (fractions 1 to 26 ) according to their TLC profile.

Fraction 10 (400 mg) was subjected to a centrifugal partition chromatography using the biphasic system cyclohexane/AcOEt/MeOH/ $\mathrm{H}_{2} \mathrm{O}$ (5:6:5:6), to give 9 fractions (fractions $10-1$ to 10-9). Fraction 10-3 was finally subjected to preparative TLC purification (silica, cyclohexane/AcOEt, 8:2) to afford spirokermeline (5) (9 mg).

Spirokermeline (5): Colorless crystalline powder. $[\alpha]_{D}^{22}=0(c=0.65$, $\left.\mathrm{CHCl}_{3}\right)$. UV (MeOH) $\lambda_{\max }\left[\log \left(\varepsilon / \mathrm{m}^{-1} \mathrm{~cm}^{-1}\right)\right]=239$ [4.6], 249 [4.1], $271 \mathrm{~nm}$ [3.6], 323 [2.6]. IR: $\tilde{v}_{\max }=1138,1372,1573,1610,1721$, $1789 \mathrm{~cm}^{-1}$. ${ }^{1} \mathrm{H}$ NMR and ${ }^{13} \mathrm{C}$ NMR, see Table 1. HRMS (ESI): calcd. for $\mathrm{C}_{30} \mathrm{H}_{38} \mathrm{O}_{5}[\mathrm{M}+\mathrm{H}]^{+}$479.279201, found 479.279259, $\Delta m=5.6 \mathrm{ppm}$.

X-ray Crystallographic Data of (5): $(M=478.60 \mathrm{~g} / \mathrm{mol})$ : space group $P 2_{1} / c, a=24.313(2) \AA, b=5.6049(4) \AA, c=22.152(2) \AA, \beta=$ $111.707(11)^{\circ}, V=2804.6(5) \AA^{3}$, Dcalc $=1.133 \mathrm{~g} / \mathrm{cm}^{3}, 30081$ reflections measured, 5438 unique $\left(R_{\mathrm{int}}=0.0708\right) . R_{1}=0.0980, \mathrm{w} R_{2}=$ $0.1640[I>2 \sigma(I)]$, and $R_{1}=0.2115, w R_{2}=0.1997$ (all data). Largest diff. peak and hole 0.132 and -0.097 e $\AA^{-3}$.

Crystallographic data of compound $\mathbf{5}$ have been deposited in the Cambridge Crystallographic Data Centre (deposit no. CCDC 1822347).

CCDC 1822347 (for 5) contains the supplementary crystallographic data for this paper. These data can be obtained free of charge from The Cambridge Crystallographic Data Centre.

\section{Acknowledgments}

The authors are very grateful to North Province of New Caledonia who facilitated our field investigations. The authors gratefully thank Dr. Vincent Dumontet and Dr. Cyril Poullain (ICSN) for the collection and identification of $K$. elliptica. We are also very grateful to Dr. B. Delpech (ICSN) and a reviewer for their sound advice on the proposed biogenetic pathway of spirokermeline and to Dr. Lieve Naesens (Rega Institute for Medical research) for the acquisition of antiviral data. This work has benefited from the facilities and expertise of the Biophysical and Structural Chemistry platform (BPCS) at IECB, Centre National de la Recherche Scientifique (CNRS) UMS3033, Inserm US001, Bordeaux University http://www.iecb.u-bordeaux.fr/index.php/ fr/plateformestechnologiques.

Keywords: Kermadecia elliptica · Lactones · Spiro compounds · Macrocycles · Natural products

[1] C. Jolly, O. Thoison, M.-T. Martin, V. Dumontet, A. Gilbert, B. Pfeiffer, S. Léonce, T. Sévenet, F. Guéritte, M. Litaudon, Phytochemistry 2008, 69, 533-540. 
[2] M. A. Beniddir, A. L. Simonin, M. T. Martin, V. Dumontet, C. Poullain, F. Guéritte, M. Litaudon, Phytochem. Lett. 2010, 3, 75-78.

[3] D. D. Ridley, E. Ritchie, W. C. Taylor, Aust. J. Chem. 1970, 23, 147-183.

[4] J. R. Cannon, P. W. Chow, M. W. Fuller, B. H. Hamilton, B. W. Metcalf, A. J. Power, Aust. J. Chem. 1973, 26, 2257-2275.

[5] M. Khazem, T. Gaslonde, V. Dumontet, C. Poullain, M. Litaudon, S. Michel, Phytochem. Lett. 2014, 10, 249-254.

[6] G. Erkel, U. Becker, T. Anke, O. Sterner, J. Antibiot. 1996, 49, 1189-1195.

[7] B. Miller, A. K. Bhattacharya, Tetrahedron Lett. 1981, 22, 3753-3756.

[8] M. Weigele, S. L. Debernardo, J. P. Tangi, W. Leimgruber, J. Am. Chem. Soc. 1972, 94, 5927-5928.
[9] Y. Malpani, R. Achary, S. Y. Kim, H. C. Jeong, P. Kim, S. B. Han, M. Kim, C.K. Lee, J. N. Kim, Y.-S. Jung, Eur. J. Med. Chem. 2013, 62, 534-544.

[10] A. M. Baldé, M. Claeys, L. A. Pieters, V. Wray, A. J. Vlietinck, Phytochemistry 1991, 30, 1024-1026.

[11] A. Lopalco, G. Dalwadi, S. Niu, R. L. Schowen, J. Douglas, V. J. Stella, J. Pharm. Sci. 2016, 105, 705-713.

[12] R. M. Letcher, N.-C. Kwok, K.-K. Cheung, J. Chem. Soc., Perkin Trans. 1 1992, 1769-1771. 